\title{
Yield Sukuk: Maturity, Rating and Value of Emission
}

\author{
Shinta Melzatia ${ }^{1}$, Caturida Meiwanto Doktoralina (Corresponding author) ${ }^{2 *}$, Mahroji ${ }^{3}$ \\ Faculty of Economy and Business, Mercu Buana University, J1. Meruya Selatan, Jakarta Barat 11650 \\ * E-mail of the corresponding author: caturida_meiwanto_drm@mercubuana.ac.id, chess302@gmail.com
}

\begin{abstract}
This study was to determine the effect of Sukuk maturity, Sukuk rating, and Sukuk emmisions value on Sukuk yield. The sample in this study was 157 corporate Sukuk issued by corporate and listed on Indonesia Stock Exchange (IDX) during the period of 2013-2016. This study used multiple regression analysis to examine the effect of Sukuk maturity, Sukuk rating and Sukuk emmisions value on Sukuk yield. The results of this study showed that the maturity of Sukuk has significant positive effect on Sukuk yield, Sukuk rating has significant negative effect on Sukuk yield, and value emissions of Sukuk has not significant effect on Sukuk yield.
\end{abstract}

Keywords: Sukuk maturity, Sukuk rating, value emissions of Sukuk, Sukuk yield

\section{INTRODUCTION}

One investment alternative in Syariah capital market is Sukuk (Jobst, Kunzel, Mills, \& Sy, 2008). Sukuk will not only strengthen the Islamic finance but also will complement the conventional bond in a significant way in the global capital market (Lebbe \& Rauf, 2013). When compared with conventional bonds the Sukuk stands better in risk sensitivity measures (Ramasamy, Munisamy, \& Helmi, 2011). Despite the diversification benefits and impressive growth of Sukuk, investing in this asset class remains challenging due to its lower liquidity. At the same time, the portfolio benefits from Sukuk are not just about liquidity; regulation also affects their risk-return profile (Hassan, Paltrinieri, Dreassi, Miani, \& Sclip, 2017).

Sukuk is not an obligation as in conventional bonds, but an investment certificate (proof of ownership) of a tangible asset or beneficial title that becomes its underlying asset International Shari'ah Research Academy for Islamic Finance/(ISRA), (2015); (Soemitra, 2017). As others investment, investors in Sukuk will get Sukuk yield as a result of an investment. The yield of Sukuk is the income that an investor obtains from investing a certain amount of money in a Sukuk. Sukuk that have a greater risk tend to get higher yields when compared with Sukuk that have a lower risk.

In a report on Kontan Investment website (Kontan, 2017) stated that the domestic Sukuk market performance in the first half of 2017 is not as high as the Sukuk market performance in the first half of 2016. Referring to Indonesia Bond Pricing Agency (IBPA) data on Wednesday (5/7) the ISIXC Total Return index, reflecting the return on investment of Sukuk, is at the level of 206.49. That means that the yield of Sukuk investment calculated since the beginning of the year only amounted to $7.52 \%$. This realisation is lower when compared to the yield in the same period last year, i.e. $10.26 \%$.

Sukuk yield reflects the Sukuk performance, which can offer information for investors in investment decision making. The above phenomenon shows that Sukuk yields fluctuate, which can be caused by changes in micro and macroeconomic conditions. The maturity of Sukuk, Sukuk ratings, and Sukuk emission value are some factors that may affect the Sukuk yield.

Research on factors affecting Sukuk yield in Indonesia has still limited that the authors are interested to examine the factors that affect Sukuk yield, especially Maturity, Rating, and Value of Sukuk Emissions. Based on the background above, the formulation of the problem in this study is 1. Does the maturity of Sukuk affect Sukuk yield? 2. Does the rating of Sukuk affect Sukuk yield? 3. Does the value emmisions of Sukuk affect Sukuk yield?

\section{Research purposes.}

The research purpose is to analyse the influence of Sukuk maturity, Sukuk rating, and value emmision of Sukuk to Sukuk yield.

\section{CONCEPTUAL FRAMEWORK OF THE STUDY}

2.1 Signalling Theory

Signalling theory is useful for describing behaviour when two parties (individuals or organisations) have access to different information. Typically, one party, the sender, must choose whether and how to communicate (or 
signal) that information, and the other party, the receiver, must choose how to interpret the signal (Connelly et al., 2010). Signal theory is an explanation of information asymmetry. The occurrence of information asymmetry is due to the management having more information about the prospect of the company. To avoid information asymmetry, companies must provide information as a signal to the investor.

\section{$2.2 \quad$ Sukuk Yield}

There are several definitions of yield, among which are (Fakhruddin, 2008:14) that yield is the income or return on investment received by the investor. Meanwhile, according to Sholihin, (2010:346) yield is a payment which may be a profit/margin/fee or other forms of payment under the Sukuk emission agreement, which is given to the Sukuk holder up to the expiry of the Sukuk period. Generally, a yield is expressed as a percentage of the capital invested.

\subsection{The Effect of Sukuk Maturity on Sukuk Yield.}

In bond issuance, the longer the maturity date, the higher the investment risk level, because in an extended period the risk of adverse events that cause the company's performance decline can occur (Rahardjo, 2003:31). Because investors bear the risk is high, the yield obtained by investors is even higher. Similarly vice versa, the shorter the Sukuk maturity, the lower the investment risks, so the yield obtained by investors is also getting smaller. Therefore, the research hypotheses stated:

$\mathrm{H}_{1}$ : Maturity of Sukuk affects Sukuk yield

\subsection{The Effect of Sukuk Rating on Sukuk Yield.}

The closer the rating of bonds to idAAA (the highest rating grade) means the better the rating and the less likely the bond will fail in fulfilling its loan obligations (Tandelilin 2001:251). This means that the higher the rating of the bond, the lower the risk faced by the investor so that the yield is getting smaller. On the contrary, the lower the bond rating, the higher the risk of investors to experience bad debts so that the yield is greater. Therefore, the research hypotheses stated:

$\mathrm{H}_{2}$ : Sukuk rating affects Sukuk yield.

\subsection{The Effect of Sukuk Emission Value on Sukuk Yield}

Bond emissions will lead to an increase in corporate leverage. Increased leverage will bring profits to the company in the form of a tax shield where the company can reduce the share of earnings paid for taxes so that the company can value from the company and provide benefits to shareholders (Afaf, 2007). It will also increase the yields of companies issuing the sharia bonds (Talahma, 2015). Following the above description can be concluded that the Sukuk emission value has positive effect on yield of Sukuk. Therefore, the research hypotheses stated:

$\mathrm{H}_{3}$ : The Sukuk Emission Value affects Sukuk yield

\section{METHODOLOGY}

\subsection{Research variable.}

The Sukuk emission value is measured in accordance with the amount of Sukuk emissions that can be obtained from the Indonesia Stock Exchange (IDX).

\subsection{Population and Sample}

The population in this study are all published corporate Sukuk and still outstanding and listed on the Indonesia Stock Exchange in 2013-2016. Population selection is determined based on specific criteria. Some of the rules used in determining the study population, i.e. First Sukuk issued by the corporation and listed on IDX during 2013-2016. Second An active, non-default, and unrestructured Sukuk.

In the sample, determination used saturated sampling technique, the technique of determining the sample when all members of the population used as a sample. The sample size is 157 outstanding corporate Sukuk during the year of study.

\subsection{Analysis Method}

Regression analysis is mostly about dependent variables with one or more independent variables, with the aim of estimating and/or predicting the average population or the mean value of the dependent variable based on the known independent value (Ghazali, 2013:95). Multiple linear regression equations in this research with the model i.e. $\mathrm{IMBAL}=\alpha-\beta_{1} \mathrm{MOS}+\beta 2 \mathrm{RS}+\beta 3 \mathrm{NES}+\mathrm{e}$ 
Information :

IMBAL $=$ Yield Sukuk

$\alpha=$ Constants

$\beta_{1}-\beta 3=$ Regression Coefficient

MOS = Maturity of Sukuk

$\mathrm{RS}=$ Sukuk Rating

NES $=$ Sukuk Emission Value

$\mathrm{e}=$ Error

\section{RESULTS AND DISCUSSION}

\section{Descriptive Statistics Test Results}

Table 4.1 Descriptive Statistics Test Results

Descriptive Statistics

\begin{tabular}{|l|r|r|r|r|r|}
\hline & \multicolumn{1}{|c|}{ N } & \multicolumn{1}{|c|}{ Min } & \multicolumn{1}{c|}{ Max } & \multicolumn{1}{c|}{ Mean } & \multicolumn{1}{c|}{ Std. Deviation } \\
\hline IMBAL & 157 & 7.42 & 13.34 & 9.9177 & 1.01309 \\
MS & 157 & 1 & 12 & 5.91 & 2.690 \\
RS & 157 & 6 & 8 & 7.22 & .903 \\
NES & 157 & 23.02 & 27.81 & 25.7576 & .90839 \\
Valid N (listwise) & 157 & & & & \\
\hline
\end{tabular}

Source: Data processed with SPSS 20

Based on the results of the descriptive statistical test (Table 4.1), can be explained as follows:

1. Data samples $(\mathrm{N})$ used and analysed in this study were 157 data samples. This descriptive statistic test is conducted on research variable that is a yield (IMBAL), Maturity Of Sukuk (MOS), Sukuk Rating (RS), and Sukuk Emission Value (NES)

2. The yield is measured from the amount of corporate Sukuk yield. Sukuk which has the smallest yield is the PLN IV Sukuk Ijarah Tahun 2010 A Series 2016 with a yield of 7.42\%. Meanwhile, Sukuk Ijarah Aneka Gas Industri II in 2012 in 2013 with 13.34\% yield. The mean yield is 9.9177, meaning that the average yield Sukuk in this study is quite high, especially when compared with the current deposit rate of $6 \%$.

3. The Sukuk maturity is measured from the length of the Sukuk due date. Sukuk maturity has the shortest tenure of 1 year, while the longest tenure is 12 years, i.e. PLN V Sukuk Ijarah Tahun 2010 B Series B. Furthermore, the Sukuk maturity mean is 5.91, means that the average Sukuk studied has long maturity.

4. The Sukuk rating is measured from ratings given by the rating agency to each Sukuk as an investment instrument. The Sukuk rating has the lowest value of 6, i.e. the transformation of the rank idA (sy) and the highest value of 8, i.e. the transformation of the rating idAAA (sy). Furthermore, the Sukuk rating mean is 7.22, the transformation from the idAA (sy) rating, which means that the average Sukuk studied has a high Sukuk rating with a standard deviation of 0.903 .

5. The Sukuk emission value is measured in accordance with the amount of the Sukuk emission in rupiah. The lowest Sukuk emission value amounted to 23.02, the Indosat Stage IV Indosat Stage IV of 2016 Series C amounting to Rp 10 billion, while the highest value of 27.81 is the Value of Sukuk Ijarah II in 2016 of Rp 1.2 Trillion. Furthermore, the mean value of Sukuk is 25.7576 or about Rp 221.94 billion.

Classic Assumption Test Normality Test Results

Table 4.2 Normality Test Results

\begin{tabular}{|l|c|}
\hline & $\begin{array}{c}\text { Unstandardized } \\
\text { Residual }\end{array}$ \\
\hline $\mathrm{N}$ & 157 \\
Asymp. Sig. (2-tailed) & 0,868 \\
\hline
\end{tabular}

Source: Data processed with SPSS 20 
Based on normality test results in Table 4.2 Asymp value. Sig. (2-tailed) is greater than $0.05(0.868>0.05)$, so it can be concluded that the yield data, Sukuk maturity, Sukuk ratings and Sukuk emission values are normally distributed.

\section{Multicollinearity Test Results.}

Table 4. 3 Multicollinearity Test Results

\begin{tabular}{|l|r|r|}
\hline \multirow{2}{*}{ Variable } & \multicolumn{2}{|c|}{ Collinearity Statistics } \\
\cline { 2 - 3 } & Tolerance & \multicolumn{1}{c|}{ VIF } \\
\hline \multirow{2}{*}{ MOS } & 0,907 & 1,103 \\
RS & 0,892 & 1,121 \\
NES & 0,827 & 1,209 \\
\hline
\end{tabular}

Source: Data processed with SPSS 20

Based on the results of multicollinearity test in Table 4.3 the tolerance values generated by each independent variable is greater than or equal to 0.10 , and the value of Variance Inflation Factor (VIF) produced by each independent variable is smaller or equal to 10. Can be concluded that there is no multicollinearity between Sukuk maturity, Sukuk ratings and Sukuk emission values in the regression model.

\section{Autocorrelation Test Results}

Table 4. 4 Autocorrelation Test Results

\begin{tabular}{|c|c|}
\hline Model & Durbin-Watson \\
\hline 1 & 1,211 \\
\hline
\end{tabular}

Source: Data processed with SPSS 20

Based on the results of the autocorrelation test in Table 4.4 Durbin Watson (DW) is 1.211, this result is between 2 and $+2(-2<1,211<+2)$, so it can be concluded that the regression model in this study is free from positive autocorrelation and autocorrelation negative.

Table 4. 5 Heteroskedasticity Test Results

\begin{tabular}{|l|c|}
\hline \multicolumn{1}{|c|}{ Variabel } & Sig. \\
\hline MOS & 0,528 \\
NS & 0,541 \\
& 0,357 \\
\hline
\end{tabular}

Source: Data processed with SPSS 20

Based on the results of heteroskedasticity test in table 4.5 no independent variable is statistically significant to affect the dependent variable. This is because all independent variables have a significant value of more than 5\%, so it can be concluded that the regression model in this study did not occur heteroscedasticity.

\section{Model Conformity Test}

Coefficient Determination (R2)

Table 4.6 Results Determination Coefficient Test (R2)

\begin{tabular}{|c|c|}
\hline Model & Adjusted R Square \\
\hline 1 & 0,317 \\
\hline
\end{tabular}

Based on the result of determination coefficient test (R2) in table 4.6 adjusted value of R2 is 0,317 . This means that the Sukuk maturity, Sukuk ratings, and Sukuk emission values can only account for $31.7 \%$ of the Sukuk yield. While other variables outside the regression model are $68.3 \%$. 


\section{Simultaneous Significance Test Result (Test F)}

Table 4. 7 Model Feasibility Test Results (F Test)
\begin{tabular}{|l|c|c|c|}
\hline & df & F & Sig. \\
\hline Regression & 3 & 25,088 & $0,000^{b}$ \\
Residual & 153 & & \\
Total & 156 & & \\
\hline
\end{tabular}

Source: Data processed with SPSS 20

Based on the result of simultaneous significance test (Test F) in table $4.7 \mathrm{~F}$ value count is 25,088 with significance level 0,000. Since the significance value is much less than $0.05(0.000<0.05)$, it can be concluded that the regression model can be used to predict the yield, or it can be said that the Sukuk maturity, Sukuk rating, and Sukuk emission value together affect the sukuk yield.

\section{Hypothesis testing}

Table 4. 8 Statistical Test Results (t-test)
\begin{tabular}{|l|c|c|}
\hline \multicolumn{1}{|c}{ Model } & t & Sig. \\
\hline (Constant) & 6,015 & 0,000 \\
MOS & 4,001 & 0,000 \\
RS & $-7,427$ & 0,000 \\
NES & $-0,142$ & 0,887 \\
\end{tabular}

Source: Data processed with SPSS 20

Based on the results of statistical tests (t-test) in Table 4.8, it can be explained that: First, Sukuk Maturity $\left(\mathrm{X}_{1}\right)$ has a value of t count of 4.001 with a significance value of $0,000(0,000<0.05)$, meaning that hypothesis 1 is accepted, the Sukuk maturity has a significant positive effect on Sukuk yield. Second, Sukuk rating $\left(\mathrm{X}_{2}\right)$ has a value of -7.427 with a significance value of $0,000(0,000<0.05)$, meaning that hypothesis 2 is accepted, that the Sukuk rating has a significant negative effect on the Sukuk yield. Third, Sukuk emission value $\left(\mathrm{X}_{3}\right)$ has a value of $t$ arithmetic of -0.142 with a significance value of $0.887(0.887>0.05)$, it means that the hypothesis 3 is rejected, the Sukuk Emission value has no significant effect on the yield of Sukuk.

\section{Multiple Linear Regression Analysis}

Table 4. 9 Multiple Linear Regression

\begin{tabular}{|l|r|r|rr|}
\hline \multirow{2}{*}{ Model } & \multicolumn{2}{|c|}{ Unstandardized Coefficients } & \multicolumn{2}{|c|}{ Standardized Coefficients } \\
\cline { 2 - 4 } & \multicolumn{1}{|c|}{ B } & \multicolumn{1}{|c|}{ Std. Error } & \\
\hline & & 2,296 & 0,278 \\
(Constant) & 13,814 & 0,026 & $-0,520$ \\
MOS & 0,105 & 0,079 & $-0,010$ \\
RS & $-0,584$ & 0,081 & \\
NES & $-0,012$ & & \\
& & & & \\
\hline
\end{tabular}

Source: Data processed with SPSS 20

Based on the above table can be obtained the regression equation as follows:

IMBAL $=13.814+0.105$ MOS -0.584 RS $-0.012 \mathrm{NES}+\mathrm{e}$

From the regression equation, it can be concluded that the constant value for the regression equation is 13.814 , it means that if the independent variable is considered constant, when independent variable $=0$, the value of the yield variable is 13.814 .

Based on the results of statistical tests $\mathrm{t}$ in table 4.8 above can be drawn the following conclusions: 


\subsection{The Effect of Sukuk Maturity On Sukuk Yield}

From the test results, Sukuk maturity has a significant positive effect on Sukuk yield. This positive relationship indicates that the longer the maturity date of a Sukuk, the higher the yield. It can be explained that in the long Sukuk maturity will face a high risk because in the extended period the occurrence risk of events that cause the company's performance decline can occur. It gives a signal to investors to expect significant returns. Vice versa that if the short Sukuk maturity, then the risks faced lower and the company is considered to be more able to pay off the Sukuk. It gives a signal to investors that the offered yield will be smaller. Therefore, the results of this study are in line with research conducted by (Purnamawati, 2013; Sari \& Abundanti, 2012; Siti \& Mulyo, 2014) stating that the maturity of a bond has a significant positive effect on bond yields.

\subsection{The Effect of Sukuk Rating on Sukuk Yield}

The Sukuk rating has a significant adverse effect on the Sukuk yield. This negative relationship shows that the higher the Sukuk rating, the lower the yield. It can be explained that the higher the Sukuk rating, the lower the risk faced by the investor, so the yield offered by the Sukuk issuer company is getting smaller. On the contrary, the lower the Sukuk rating, the higher the investor risk on its investment in the Sukuk so that the yield offered by the Sukuk issuer company is getting higher. Companies with low Sukuk ratings will provide high returns to attract investors as compensation for the possibility of higher risk. Bond ratings have a significant adverse effect on bond yields. Therefore the results of this study also support research (Sari \& Abundanti, 2012; Siti \& Mulyo, 2014).

\subsection{The Effect of Sukuk Emission Value On Sukuk Yield}

The Sukuk Emission Value has no significant effect on the Sukuk yield. The Sukuk emission value is deemed to have insufficient information on the decision taken by the investor. However, it does not mean that the information on the Sukuk emission value of the company does not provide any information on the decision to be taken by the investor, since the value of the Sukuk emission can show the level of liquidity and solvency of the company in the short and long term that can be useful for investors. Although in this case, the effect is very small or even negligible. In this study, the Sukuk Emission Value information individually is not taken into consideration by the investor in decision making so that the Sukuk emission value does not affect the yield. The results show that there is no effect on the value of Sukuk emissions on these yields in line with research conducted by (Anggraini, 2017).

\section{CONCLUSION AND SUGGESTION}

Based on the results of the analysis and discussion, the conclusions are, i.e. First, Sukuk maturity has a significant positive effect on the Sukuk yield. Second, Sukuk rating has a significant adverse impact on the Sukuk yield. Third, Sukuk emission value has no significant effect on the Sukuk yield. Besides, with time constraints and research gaps by the author and suggestions that can be given for further research improvements, i.e. First, For the Sukuk issuer company in Indonesia, it is expected to pay attention to the Sukuk maturity and Sukuk rating because both variables can affect the Sukuk yield on all Sukuk issuer companies in Indonesia. Second, For further research, it is expected to add another independent variable that can influence the yield of Sukuk so that the result will further strengthen the effect of the yield given by the Sukuk issuer company in Indonesia. Besides, it is expected to examine with different and more extended periods of time to obtain better results and analyse different Sukuk types such as Sovereign Sukuk .

\section{References}

Afaf, N. (2007). Analisis pengaruh pengumuman penerbitan obligasi terhadap return saham di bursa efek Jakarta. Institut Pertanian Bogor.

Anggraini, W. (2017). Pengaruh Nilai dan Rating Penerbitan Obligasi Syariah (Sukuk) Perusahaan Terhadap Return Saham pada Perusahaan-Perusahaan yang Menerbitkan Obligasi Syariah. UIN Raden Fatah Palembang.

Fakhruddin, H. M. (2008). Istilah pasar modal AZ: berisi kumpulan istilah populer pasar modal khususnya di pasar modal Indonesia, mencakup berbagai istilah seputar perdagangan saham, obligasi, reksa dana, instrumen derivatif dan berbagai istilah terkait lainnya. Elex Media Komputindo.

Ghazali, I. (2013). Aplikasi Analisis Multivariate Dengan Program IBM SPSS 21 Update PLS Regresi. Semarang: Badan Penerbit Universitas Diponegoro.

Haningsih, L., Zulkifli, Z., \& Doktoralina, C. M. (2017). Pengaruh Total Asset Turn Over, Return on Asset dan Return on Equity terhadap Accumulation Distribution Line. Jurnal Akuntansi, 18(3), 438-458. 
Hassan, M. K., Paltrinieri, A., Dreassi, A., Miani, S., \& Sclip, A. (2017). The determinants of co-movement dynamics between sukuk and conventional bonds. Quarterly Review of Economics and Finance. http://doi.org/10.1016/j.qref.2017.09.003

International Shari'ah Research Academy for Islamic Finance (ISRA). (2015). Sistem Keuangan Islam: Prisnsip dan Operasi. In Jakarta: Rajawali Pers.

Jobst, A., Kunzel, P., Mills, P., \& Sy, A. (2008). Islamic bond issuance: what sovereign debt managers need to know. International Journal of Islamic and Middle Eastern Finance and Management, 1(4), 330-344.

Kontan. (2017). Kinerja indeks Sukuk melambat di semester I 2017. Retrieved June 11, 2018, from https://investasi.kontan.co.id

Lebbe, A., \& Rauf, A. (2013). Emerging Role For Sukuk in The Capital Market. South East Asia Journal of Contemporary Business, Economics and Law, 2(2), 41-45.

Purnamawati, I. G. A. (2013). Pengaruh Peringkat Obligasi, Tingkat Suku Bunga-Sertifikat Bank Indonesia, Rasio Leverage, Ukuran Perusahaan Dan Umur Obligasi Pada Imbal Hasil Obligasi Korporasi Di Bursa Efek Indonesia. Jurnal Jurusan Akuntansi (D3)/Vokasi Jurnal Riset Akuntansi, 2(1).

Rahardjo, S. (2003). Panduan investasi obligasi. Jakarta: Gramedia Pustaka Utama.

Ramasamy, R., Munisamy, S., \& Helmi, M. H. M. (2011). Relative Risk Of Islamic Sukuk Over Government And Conventional Bonds. Global Journal of Management and Business Research, 11(6), 1-9.

Sari, P. I., \& Abundanti, N. (2012). Pengaruh pertumbuhan perusahaan dan leverage terhadap profitabilitas dan nilai perusahaan. The Indonesian Publication Index, 1427-1441.

Sholihin, A. I. (2010). Buku Pintar Ekonomi Syariah. PT Gramedia Pustaka Utama.

Siti, H. A., \& Mulyo, H. A. (2014). Analisis Faktor-faktor yang mempengaruhi Yield Obligasi Korporasi (Studi Kasus pada Seluruh Perusahaan Penerbit Obligasi yang Terdaftar di BEI Periode 2010-2012). Fakultas Ekonomika dan Bisnis.

Soemitra, A. (2017). Bank \& Lembaga Keuangan Syariah. Prenada Media.

Talahma, K. I. (2015). Islamic Bonds (Sukuk): Opportunities and Challenges. Asper Rev. Int'l Bus. \& Trade L., $15,391$.

Tandelilin, E. (2001). Analisis investasi dan manajemen portofolio. Yogyakarta: BPFE. 